\title{
Crazy Ant, Paratrechina longicornis (Latreille) (Insecta: Hymenoptera: Formicidae) 1
}

J. C. Nickerson and K. A. Barbara ${ }^{2}$

\section{Introduction}

Crazy ants, Paratrechina longicornis (Latreille), occurs in large numbers in homes or outdoors. They often forage long distances away from their nests, so nests are often difficult to control. The name "crazy ant" arises from its characteristic erratic and rapid movement not following trails as often as other ants. The crazy ant is so morphologically distinctive that it is one of the few Paratrechina that is not consistently misidentified in collections (Trager 1984).

\section{Synonymy (from Creighton 1950) is:}

Formica longicornis Latreille (1802)

Prenolepis longicornis Roger (1863)

Prenolepis (Nylanderia) longicornis Emery (1910)

Formica vagans Jerdon (1851)

Formica gracilescens Nylander (1856)

Tapinoma gracilescens F. Smith (1858)
Paratrechina currens Motschoulsky (1863)

Paratrechina longicornis (Latreille) (1925)

\section{Distribution}

The crazy ant is found in various parts of the world and is not native to the United States (Smith 1965). It is of Asian or African origin but is found in tropical cities worldwide (Trager 1984). In the United States the crazy ant can be found from Florida to South Carolina and west to Texas. It also is found in residences and warehouses over much of the eastern U.S. (Creighton 1950) and in California and Arizona (Trager 1984).

\section{Description}

The antennae of the crazy ant have 12-segments without a club and are extremely long. The crazy ant worker is relatively small $(2.3-3 \mathrm{~mm})$. All workers in a crazy ant colony are monomorphic and have only one node between the propodeum and the gaster. The scape, the basal segment of the antenna, is extraordinarily long with the apex surpassing the posterior border of the head by at least one-half the

1. This document is EENY-142, one of a series of Featured Creatures from the Entomology and Nematology Department, Florida Cooperative Extension Service, Institute of Food and Agricultural Sciences, University of Florida. Published: June 2000. This document is also available on Featured Creatures Website at http://creatures.ifas.ufl.edu. Please visit the EDIS Website at http://edis.ifas.ufl.edu. Additional information on these organisms, including many color photographs, is available at the Entomology and Nematology Department WWW site at http://entnemdept.ifas.ufl.edu/.

2. J. C. Nickerson, Florida Department of Agriculture, Division of Plant Industry, Gainesville, FL and K. A. Barbara, Entomology and Nematology Department, University of Florida, Insititute of Food and Agricultural Sciences, Gainesville, FL 32611.

The Institute of Food and Agricultural Sciences is an equal opportunity/affirmative action employer authorized to provide research, educational information and other services only to individuals and institutions that function without regard to race, color, sex, age, handicap, or national origin. For information on obtaining other extension publications, contact your county Cooperative Extension Service office. Florida Cooperative Extension Service/Institute of Food and Agricultural Sciences/University of Florida/Christine Taylor Waddill, Dean. 


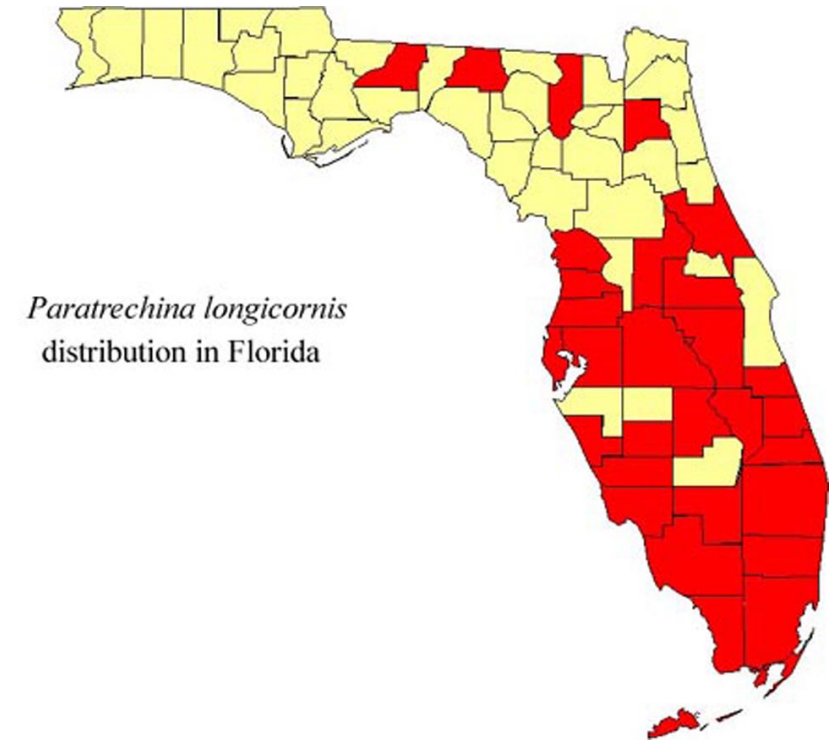

Figure 1. Crazy ant, Paratrechina longicornis (Latreille), distribution in Florida, as of June, 2000. Credits: Kathryn A. Barbara, University of Florida

scape length. Eyes are elliptical, strongly convex, and placed close to the posterior border of the head. Legs are extraordinarily long. The petiole is wedge-shaped, with a broad base, and inclined forward. A small round terminal orifice surrounded by a fringe of setae, or hairs, the acedipore serves for the application of venom both in defense and predation. The stinger is lacking but the crazy may bite an intruder and curve its abdomen forward to inject a formic acid secretion onto the wound. The body has long, coarse, well scattered, suberect to erect, grayish or whitish setae. The head, thorax, petiole, and gaster are dark brown to blackish (Creighton, 1950); the body often has faint bluish iridescence.

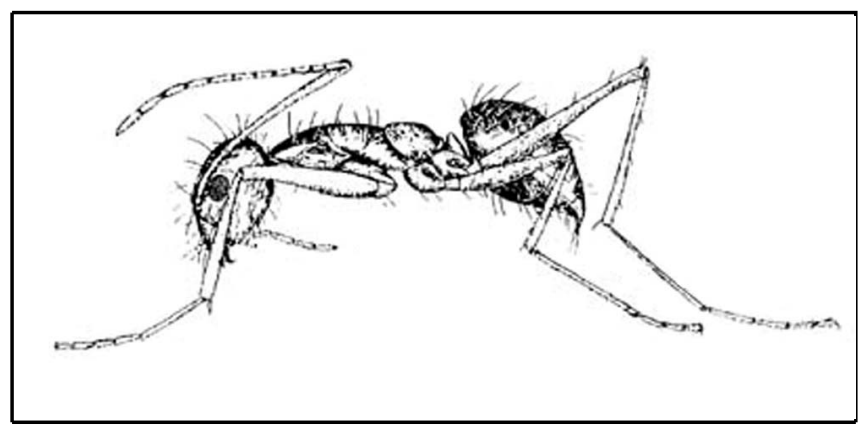

Figure 2. Lateral View of crazy ant. Credits: University of Florida

The crazy ant is extremely easy to identify on sight by observing its rapid and erratic movements. Confirmation may be made with the aid of a hand lens through which the extremely long antennal

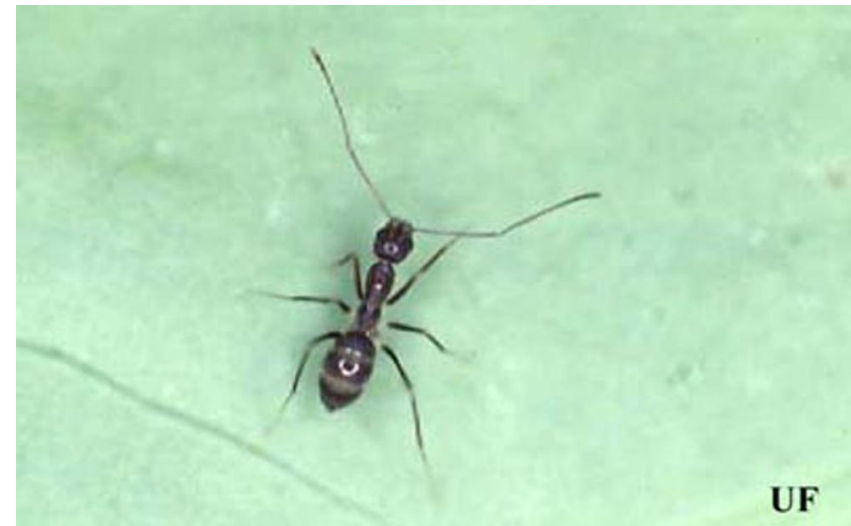

Figure 3. Dorsal view of a crazy ant, Paratrechina longicornis (Latreille), worker. Credits: James Castner, University of Florida

scape, long legs, and erect setae are very apparent. The slender- bodied, long-legged worker is capable of extremely rapid movement.

\section{Life Cycle}

Colonies of crazy ants are moderate to very populous. The colonies may raise sexuals at any time of the year in warmer regions, but in the seasonal climate of north Florida, alate production is apparently limited to the warm rainy months of May through September (Trager 1984). On warm, humid evenings, large numbers of males gather outside nest entrances and may mill about excitedly. Workers patrol vegetation and other structures nearby. Periodically, a dealate queen emerges. Mating was not observed, but Trager (1984) suggested that it occurred in such groupings around the nest entrance. Wings of queens are removed while still callow and males were never observed to fly or use their wings in any way. However, in several cases it has been observed that males frequently appear at lights (Trager 1984).

\section{Pest Status}

The crazy ant has achieved pest status across the United States. It has been found on top floors of large apartment buildings in New York, hotels and flats in Boston and in hotel kitchens in San Francisco, California.

Marlatt (1930) observed that the crazy ant is a pest in Florida and the Gulf States. In 1977, modular units, serving as temporary schoolrooms, were being 
used by a North Lauderdale elementary school. The principal reported that the units were so inundated by the ant that students were constantly in a state of turmoil. The invasion reached such proportions that the students' sack lunches were kept in closed plastic bags placed on tables with each table leg sitting in a pan of water as a barrier to the ant.

\section{Foraging and Feeding}

Workers are omnivorous, feeding on live and dead insects, seeds, honeydew, fruits, plant exudates, and many household foods. The crazy ant thrives in places such as gasoline stations, convenience stores, and sidewalk cafes where workers may be seen transporting crumbs and insects attracted to lights. They apparently have a seasonal preference for a high-protein diet, and during the summer months may refuse honey or sugar baits. They are attracted to honeydew producing homopterans in spring and fall. They obtain honeydew by tending aphids, mealybugs, and soft scales (Smith 1965). Large prey items are carried by a highly concerted group action (Trager 1984).

The workers are known to gather small seeds of such crops as lettuce and tobacco from seedbeds. In cold climates, the ants nest in apartments and other buildings where they are potential pests year round. Workers feed on many household foods such as meats, grease, sweets, fruits, vegetables, and liquids (Smith 1965).

\section{Nest Sites}

The crazy ant is highly adaptable, living in both very dry and rather moist habitats. The crazy ant often nests some distance away from its foraging area. It nests in such places as trash, refuse, cavities in plants and trees, rotten wood, in soil under objects and also have been found under debris left standing in buildings for long periods of time (Smith 1965). These ants can nest in a variety of locations from dry to moist environments. A crazy ant nest site can be found by looking for workers carrying food back to the nest.

\section{Management}

Non-chemical control is based on exclusion through good housekeeping practices and cleanliness eliminating food sources. Crazy ants nest outdoors so prevention of their entrance by caulking exterior penetrations and weather-stripping may aid in their control. Indoors chemical controls are based on baits, dusts, and spot treatments with residual sprays. Outdoor treatments include chemical formulations as baits, granules, dusts, and sprays. Read and follow label instructions and precautions before using any insecticide.

For more information see:

Insect Management Guide for Ants

Ant Trails: A Key to Control with Baits

\section{Selected References}

Creighton, W.S. 1950. The ants of North America. Bull. Mus. Comp. Zool. 104. 585 p.

Koehler, P.G., D.E.Short and T.R. Fasulo. (1998). Pests In and Around the Home UF/IFAS. SW-126. CD-ROM.

Mallis, A. 1997. Handbook of Pest Control - The Behavior, Life History, and Control of Household Pests. 7th Edition. Franzak \& Foster Co. Cleveland. 1990. $1152 \mathrm{p}$.

Marlatt, C.L. 1930. House ants. Kinds and methods of control. USDA Farmer's Bull. 740. 12 p.

Smith, M.R. 1965. House-infesting ants of the eastern United States; their recognition, biology, and economic importance. USDA Tech. Bull. 1326. 105 p.

Trager, J.C. 1984. A revision of the genus Paratrechina (Hymenoptera: Formicidae) of the continental United States. Sociobiology 9: 51-162.

Wilson, E.O., and R.W. Taylor. 1967. The ants of Polynesia (Hymenoptera: Formicidae). Pacific Insects Monograph 14. 109 p. 